\title{
Semiospherical understanding: Textuality
}

\author{
Peeter Torop \\ Dept. of Semiotics, University of Tartu \\ Tiigi St. 78, 50410 Tartu, Estonia \\ e-mail: torop@ut.ee
}

\begin{abstract}
The semiospherical approach to semiotics and especially to semiotics of culture entails the need of juxtaposing several terminological fields. Among the most important, the fields of textuality, chronotopicality, and multimodality or multimediality should be listed. Textuality in this paper denotes a general principle with the help of which it is possible to observe and to interpret different aspects of the workings of culture. Textuality combines in itself text as a well-defined artefact and textualization as an abstraction (presentation or definition as text). In culture, we can pose in principle the same questions both to a concrete and to an abstract text, although an abstract text is only an operational means for defining, with the help of textualization, a certain phenomenon in the interests of a holistic and systemic analysis. The practice of textualization in turn helps us to understand the necessity of distinguishing between articulation emerging from the textual material itself and articulation ensuing from textuality or textualization - the former provides for comparability between texts made from the same material, the latter makes comparable all textualized phenomena irrespective of their material. Textuality is a possibility that culture offers to its analyser, and at the same time it is an ontological property of culture and an epistemological principle for investigating culture.
\end{abstract}

The relevance of semiotics is increasing both in science and in culture. On the one hand, semiotics offers methodological support to the sciences the development of which has been bound up with interdisciplinary dialogue with other sciences and which are in need of methodological innovation in order to locate their shifted borders. On the other hand, culture and nature as the environment of human life have also changed, and this, in turn, requires a new understanding of how to comprehend and explain this changed environment or, in other 
words, how to define epistemologically the object of inquiry. Thus, the disciplinary structure of sciences has changed, interdisciplinarity has given rise to new types of scientific dialogue in the form of multi-, cross- or transdisciplinarity, but at the same time also objects of sciences have changed. Especially in the humanities and in the social sciences, due to the (technological) development of media environment and due to the creolization and hybridisation of languages of culture, objects of research have changed so rapidly that semiotics has become both a methodological as well as an applicational resource for securing sustainable development of these sciences. Traditional science and traditional culture have arrived at a stage where fragmented understanding of culture, society and nature has reached a crisis of holism. Restoration of holistic approach presupposes that the methodological principles of applicational analysis of culture, of the sciences that investigate culture, and the principles of cultural autocommunication and identity education are fruitfully combined into a unified whole. Compared to other sciences, semiotics has great advantages in creating such symbiosis.

One of the founders of the Tartu-Moscow School of Semiotics, Vyatcheslav Vs. Ivanov, has concluded his study "The outlines of the prehistory and history of semiotics" with an epilogue where he emphasizes both the scientific as well as the social value of semiotics and defines the main task of semiotics: "The task of semiotics is to describe the semiosphere without which the noosphere is inconceivable. Semiotics has to help us in orienting in history. The joint effort of all those who have been active in this science or the whole cycle of sciences must contribute to the ultimate future establishment of semiotics" (Ivanov 1998: 792).

The semiospherical approach to semiotics and especially to semiotics of culture entails the need of juxtaposing several terminological fields. Among the most important, the fields of textuality, chronotopicality, and multimodality or multimediality should be listed.

The field of textuality is related to the development of semiotics of culture, especially in view of the works of J. Lotman; the field of chronotopicality originated in the works of Mikhail Bakhtin, and the field of multimodality (multimediality) is connected at its roots with the works of Roman Jakobson. It is the interweaving of these three terminological and conceptual fields that has brought about both methodological and metalinguistic interference, as a result of which we now have to speak about creolization and hybridization of 
metalanguage. But the same processes take place also inside these fields and therefore it would be expedient to investigate the three fields first of all individually. The present paper is devoted to the first one of these, the field of textuality.

\section{Textuality}

Textuality in this paper denotes a general principle with the help of which it is possible to observe and to interpret different aspects of the workings of culture. The concept of textuality is meant to bridge two poles between which the main problems of describing and explaining cultures are located. One pole is marked by the opposition statics dynamics, the other by the opposition part-whole. These two pairs of concepts are in fact closely related and their separation into two poles is necessary only for observing temporal dynamics. Through the concept of textuality, also the productivity of cultural-semiotic way of reasoning and the ability of semiotics of culture to function as a foundation science for other disciplines studying culture will become apparent.

The concept of textuality merges several questions that are methodologically relevant for all the disciplines investigating culture. First of all, there is the question of models that are used to describe culture. There does not exist a general science of culture as a separate discipline, and therefore a general study of culture must take into account the different notions that different disciplines have of this universal research object, and to look for correlations between different models of culture.

Models of culture are methodologically designed and metalinguistically formulated by the disciplines that have created them, and therefore it is vital that a general treatment of culture identifies the autonomy and blending of description languages and takes into account the metalinguistic translation process. Besides the characteristics of the description language, deriving from the specificity of a particular cultural model, also the existence of prestige languages in culture and the tendency of several research areas to translate themselves into the prestige language should be taken into account. Therefore, in some cases there is no direct correspondence between the object described, the describing discipline and the description language used. This brings us to the issue of relations that a meta- 
language has with the object described and with other metalanguages or a prestige language.

Between culture as a complex research object and culture as a functioning system, or, methodologically speaking, between description languages (metalanguages) of culture and (object language(s) of) the process of culture there is a linguistically heterogeneous sphere of culture's self-description. In the self-description of culture, metaand object levels are not usually easily discernible, as self-description is a dynamic autocommunicative process that is difficult to observe due to its mutability. An answer to the question of the observability of culture's self-description can be sought, through the concept of textuality, foremost from the aspect of the relations between communication and metacommunication.

Another issue that arises in connection with a dynamic research object is the definition of research- or articulation units. Textuality combines in itself text as a well-defined artefact and textualization as an abstraction (presentation or definition as text). In culture, we can pose in principle the same questions both to a concrete and to an abstract text, although an abstract text is only an operational means for defining, with the help of textualization, a certain phenomenon in the interests of a holistic and systemic analysis. The practice of textualization in turn helps us to understand the necessity of distinguishing between articulation emerging from the textual material itself and articulation ensuing from textuality or textualization - the former provides for comparability between texts made from the same material, the latter makes comparable all textualized phenomena irrespective of their material.

The question of textuality is also a question of understanding the ontology of text. Both the ontology of text and the stance toward it have gradually altered in relation to many changes in culture. First, there can be observed a decrease in logocentrism and increase in the role of visual and audiovisual perception, and consequently it has to be acknowledged that there has been a shift in the hierarchy of perception channels in culture. An early and intensive visual experience leaves its mark also on traditional spheres of culture, and therefore, with each successive generation, there is reason to speak about changed attitudes with respect to literature, theatre, cinema or art, and, accordingly, also about changes in the relationships between those areas in culture. Secondly, processes of culture are so intensive and so diffuse that perceptual processes have become complementary: 
the consumption of metatexts can precede the consumption of the texts themselves, or, in other words, the boundary between the properties of being primary or secondary is not always visible nor important. Another important feature is the perception of a single event in communities of different types - in intertextual, interdiscursive or intermedial spaces. This, in turn, brings about transformation in whole-part relationships: the diffuse existence of a whole causes the autonomy of parts, and on the principle of pars pro toto, the whole may be represented by very different parts, while the relationship of parts with the whole can be implicit, discernible only to an expert. Hence, also the expert's mission in culture has changed, since the observing of a diffused whole and the uniting of diffused parts into a whole are becoming an important activity securing the coherence of culture, observing, diagnosing and making prognoses for the functioning of culture as a whole. The emergence of new processes in culture has created a double identity for texts: on the one hand, every text is a result of individual creation, while on the other hand, a text exists in culture as a diffuse mental whole and subsists in this form in the collective cultural memory. A mental text is an abstract whole the structure of which depends on the amount and types of textual transformations (including transformations of text's parts) in a given culture or, more narrowly, in a given cultural situation. Following from the principle of textuality, investigation of a text means juxtaposing both individual and cultural ontologies, juxtaposing both in time and in space.

\section{Synchrony and diachrony as statics and dynamics}

Polemics with F. de Saussure has influenced the development of ideas of several disciplinary trends, including Russian formalism, Prague Linguistic Circle and Danish glossematics. F. de Saussure's Cours de linguistique générale contrasts synchrony and diachrony, denying at the same time the possibility of panchronic analysis of concrete linguistic facts. The reason for this lies in the divergent nature of facts belonging to the diachronic order and to the synchronic order. It is characteristic that F. de Saussure deliberately avoids the term "historical linguistics" and he prefers, when contrasting the two linguistics, to use the term "evolutionary linguistics" to denote the branch investigating the succession of linguistic states, and the term "static 
linguistics" to denote the branch investigating the linguistic states themselves. In order to secure greater clarity in this contrast, F. de Saussure started calling anything related to statics, "synchrony", and anything related to evolution, "diachrony" (Saussure 1977: 114).

One of the leading figures of Russian Formalism, in many ways yet undiscovered J. Tynianov, wrote in his 1924 paper "Literary fact": "Literary fact is heterogeneous, and in this sense literature is an incessantly evolutioning order" (Tynianov 1977: 270). A few years later in the paper "On literary evolution" (1927) he specifies that the study of literary history needs to address also the living contemporary literature. As Tynianov claims, historical studies of literature were until then occupied either with the genesis of literary phenomena or with the evolution of literary order (Tynianov 1977: 271). The question of literary order or system is for Tynianov inseparable from the question of function:

A literary system is first of all a system of the functions of the literary order which are in continual interrelationship with other orders. Systems change in their composition, but the differentiation of human activities remains. The evolution of literature, as of other cultural system, does not coincide either in tempo or in character with the systems with which it is interrelated. This is owing to the specificity of the material with which it is concerned. The evolution of the structural function occurs rapidly; the evolution of the literary function occurs over epochs; and the evolution of the functions of a whole literary system in relation to neighbouring systems occurs over centuries. (Tynianov 1977: 277)

In Tynianov's system, we can observe the relatedness of literary order to other orders - with the order of everyday life, the order of culture, social order. Everyday life is correlated with literary order in its verbal aspect, and thus, literature has a verbal function in relation to everyday life. An author's attitude towards the elements of his text expresses structural function, and the same text as a literary work has literary function in its relations to the literary order. The return influence of literature on everyday life, again, expresses social function. The study of literary evolution presupposes the investigation of connections first of all between the closest neighbouring orders or systems, and the logical path leads from the structural to the literary function, from the literary to the verbal function. This follows from the position that "evolution is the change in interrelationships between the elements of a system - between functions and formal elements" (Tynianov 1977: 
281; see also Torop 1995-1996). Hence, evolution is understood as the alternation of systems (at times, alternation is slow and continuous; at times, abrupt) where formal elements do not disappear but gain new functions. It is necessary to understand that a system is not a reciprocal influence of all the elements: some elements have greater import (dominant) and deform others, and it is through the dominant that a work gains its literary importance (Tynianov 1977: 277). The interpretation of the structural function coincides to a large extent with the interpretation of the dominant, since the relations between the elements of a work can be described in at least two ways. Every element of a work can be juxtaposed with other similar elements in other works-systems, even in other orders - this is called "synfunction" by Tynianov. At the same time, each element is related to other elements of its own system, which is called "auto-function" by Tynianov (1977: 272). Thus, each element has at least two functional parameters.

Better known in the modern reception of Tynianov's works is the opposition genesis and tradition, originally presented in his earlier article "Tyutchev and Heine" (1922). Genesis of a literary phenomenon belongs to the sphere of accidental transferences from a language into another language, from a literature into another literature, while tradition refers to regularities taking place within one particular national literature (Tynianov 1977: 29). Thus, also genesis and tradition constitute two parameters of one phenomenon, and these two parameters need to be juxtaposed in order to get a maximally multifaceted picture of reality. The distinction between genesis and tradition makes it possible, in the case of one and the same text, to speak about text of genesis and text of tradition. Text of genesis is an implicit system reflecting the subjectivity and the fortuitous nature of the creative process, a system that a researcher can reconstruct as unique. Text of tradition, on the other hand, expresses explicit belonging to a movement, style, grouping or genre, as well as causal or typological relations with predecessors or successors. A text exhibiting explicit characteristics of classicism or romanticism is certainly a text of tradition, but at the same time it does not lose its uniqueness, which remains present in the implicit authorial poetics and in which text of genesis can be discerned. Whether it is text of tradition, text of genesis or their symbiosis — what is searched for in a literary text depends on the epoch and on the reader. 
The movement of Russian Formalism toward Prague Linguistic Circle is marked by a programmatic article "Problems of investigating literature and language" (1928), written jointly by J. Tynianov and R. Jakobson. This short research program reveals already a direct polemics with F. de Saussure. The authors object to the opposition of synchrony and diachrony on the grounds that in reality these two cannot be studied in isolation:

History of a system is in turn a system. Pure synchronism now proves to be an illusion: every synchronic system has its past and its future as inseparable structural elements of the system $[\ldots]$. The opposition between synchrony and diachrony was an opposition between the concept of system and the concept of evolution; thus it loses its importance in principle as soon as we recognize that every system necessarily exists as an evolution, whereas, on the other hand, evolution is inescapably of a systemic nature. (Tynianov 1977: 282)

Therefore, what is of foremost importance in this approach is the understanding that synchrony incorporates different time periods, that each cross-segment of synchrony may be related to most different epochs:

The concept of a synchronic literary system does not coincide with the naively envisaged concept of a chronological epoch, since the former embraces not only works of art which are close to each other in time but also works which are drawn into the orbit of the system from foreign literatures or previous epochs. An indifferent cataloguing of coexisting phenomena is not sufficient; what is important is their hierarchical significance for the given epoch. (Tynianov 1977: 283)

On the other hand, it is emphasized that the identification of immanent regularities of literary history should be inseparably connected with the identification of the ways in which literary order and other historical orders (systems) relate to each other. Relatedness as a system of systems has its own structural laws that need to be identified. The authors caution us against isolated study: "It would be methodologically fatal to consider the correlation of systems without taking into account the immanent laws of each system" (Tynianov 1977: 283). In the program of J. Tynianov and R. Jakobson, it is possible to foresee the modern juxtaposition of text of history and text of culture as parameters of a single text.

In linguistics, the same trend is continued during the 1930-1940s by the Danish glossematician L. Hjelmslev. He starts out with an 
observation that humanities have neglected their most important task - to establish the investigation of social phenomena as a science. The description of social phenomena must choose between two possibilities.

The first possibility is poetic description; the second possibility lies in the combination of poetic and scientific treatment as two coordinate forms of description. The choice between the two possibilities should proceed from an answer to the question whether a process has an underlying system:

\begin{abstract}
A priori it would seem to be a generally valid thesis that for every process [including historical processes] there is a corresponding system, by which the process can be analysed and described by means of a limited number of premisses. It must be assumed that any process can be analysed into a limited number of elements recurring in various combinations. Then, on the basis of this analysis, it should be possible to order these elements into classes according to their possibilities of combination. (Hjelmslev 1963: 9)
\end{abstract}

In L. Hjelmslev's view, it should be feasible to calculate the number of all possible combinations, and this would yield a much more objective description: "A history so established should rise above the level of mere primitive description to that of a systematic, exact, and generalizing science, in the theory of which all events (possible combinations of elements) are foreseen" (Hjelmslev 1963: 9). L. Hjelmslev juxtaposes process as a relational (both-and function) hierarchy and system as a correlational (either-or function) hierarchy, associating these terms also with text and language, respectively. What is noteworthy here is not the association of this opposition with the treatment of paradigmatics and syntagmatics (especially in the works of R. Jakobson), but L. Hjelmslev's aim to create separate metalanguages for investigating system and process. Thus, a process would be investigated in one metalanguage and the system underlying this process would be investigated in another metalanguage, although the two metalanguages would be correlated with each other. This is exactly the issue that is encountered by researchers who attempt to analyse, e.g., a literary work as simultaneously a historical phenomenon and as a contemporary with a particular epoch. In such case, metalinguistic bilingualism would help to avoid mixed language. To extend this logic further, L. Hjelmslev's innovative insight could be marked with the terminological pair text of system and text of process, where text as system and text as process would manifest only as 
special cases of this opposition. Although to a different degree, the dimension of history would be present in both descriptions, similarly to the case of J. Tynianov's concepts of genesis and tradition.

Closer to the present time, among the manifestations of the same trend of thinking the New Historicist approach should be mentioned first, in whose vocabulary "historical context" has been substituted with "cultural system" and where relations between text and culture are seen as inherently intertextual, with intertextuality taking place between two types of text, text of literature and text of culture (see White 1989: 294). Any literary event is therefore a diachronic text of the autonomous history of literature and a synchronic text of the cultural system (White 1989: 301).

An example of the further development of the same line of thinking is provided by A. Assmann's concept of cultural text. As a subsystem of culture, literature itself is also a cultural text; however, one and the same text has different properties as a literary text and as a cultural text. From the aspect of the relationship of identity, a literary text is a means of individual communication, while for a cultural text, a reader is foremost a representative of a group or a community. From the viewpoint of reception, between a receiver and a literary text there is an aesthetic distance, while in the case of a cultural text, there is an insistence on truth. From the aspect of innovation and canonicity, literary text strives toward innovation, while cultural text is associated with canonization. From the aspect of resistance to time, the background system for literary text is formed of history, of different readings done by different generations, while for cultural text, the background system is average tradition (Assmann 1995). Of course, the relations of cultural text and literary text are more complicated than that. Texts with prestige such as the Classics or the Bible function above all as cultural texts. On the other hand, cultural text can bring about the emergence of literary text, as can be witnessed in the case of salon literature or album verse.

The study of a text in culture is inseparable from the search for parameters in order to characterize the different functions of the text. Every text has its own history and at the same time it exists in general history; every text is contemporary and historical at the same time. Every text is a framed whole and as such, unchangeable. At the same time, each text is a part of culture (of cultural situation and of cultural history) and as such, ambiguous, multifunctional and changing. text of culture and text of literature (or text of any other form of art) can be 
different forms of existence of the same text, they can be contained in each other as a part is contained in a whole, they can be autonomous wholes, temporal or atemporal, concrete or abstract, static or dynamic; however, with all these oppositions the boundary between the two sides will remain vague and ambivalent. Pure diachrony and synchrony or pure statics and dynamics are but idealized concepts. Therefore, in this context it would often be more accurate to speak not about texts, but about textuality, about complicated relations in time and space for the description of which it is convenient to use the operational term "text". Becoming a text and being as text have to do in the analysis of cultural phenomena both with ontology and epistemology and help to understand culture as a hierarchy of (textual) identities.

\section{Textuality, metatextuality, and intertextuality}

In parallel and in relation to the linguistically oriented developments there emerged similar issues also in the anthropological disciplines. At the end of the 1950s, C. Lévi-Strauss wrote in his book Structural Anthropology (1958) about the necessity to describe rules of marriage and kinship systems as a kind of language, serving as a means of communication between individuals and groups of individuals. In the year 1973 C. Geertz voices his objection to isolated descriptions that stem from ethnographic fieldwork. His book The Interpretation of Cultures provides an example of textualization of description of culture. Here, interpretative anthropology forms a parallel to semiotics of culture. C. Geertz's concept of thick description refers to the ability of a researcher to explicate or reconstruct the whole on the basis of very heterogeneous, commingled or ambivalent data. In such approach, a foreign culture becomes an acted document that can be interpreted in communication. This document is comparable to a foreign and incoherent manuscript where graphic signs are replaced by examples of behaviour (Geertz 1993: 10). Such text of behaviour is one example of how a complex research object can be textualized.

Textuality as a methodological principle has a significant role also in the development of the Tartu-Moscow School of Semiotics. One of the most renowned members of the school, A. Pyatigorski, has post factum observed that this tradition started out with an undelimited research object. While in the first works at the beginning of the 1960s 
the object of semiotics was "anything", then after the publication of J. Lotman's first semiotic book Lectures on Structural Poetics (1964) the object became specified as literature:

In Lotman's "Lectures", a huge role was played by the introduction of the term "text" as a fundamental concept of semiotics and at the same time, as a neutral concept with respect to its object, literature. It was precisely the concept of "text" which made it possible for Juri Mikhailovich to pass from literature over to culture as a universal object of semiotics. (Pyatigorskij 1996: $54-55)$

"Theses on the Semiotic Study of Cultures" (1973), the programmatic work of the Tartu-Moscow School, defines semiotics of culture as a science investigating the functional correlation of different sign systems, which proceeds from the position that "none of the sign systems possesses a mechanism which would enable it to function culturally in isolation" (Theses 1998: 33). Text has been defined in "Theses" as a bridging link between a general semiotic and a concrete empirical investigation:

The text has integral meaning and integral function (if we distinguish between the position of the investigator of culture and the position of its carrier, then from the point of view of the former the text appears as the carrier of integral function, while from the position of the latter it is the carrier of integral meaning). In this sense it may be regarded as the primary element (basic unit) of culture. The relationship of the text with the whole of culture and with its system of codes is shown by the fact that on different levels the same message may appear as a text, part of a text, or an entire set of texts. (Theses 1998: 38)

In the tradition of the Tartu-Moscow School, the concept of text is, above all, dynamic: text can be an integral sign or a sequence of signs; it can be a part or a whole. On the other hand, a text can be a linguistically concrete text of language or a culturally concrete text of culture:

In defining culture as a certain secondary language, we introduce the concept of a "culture text", a text in this secondary language. So long as some natural language is a part of the language of culture, there arises the question of the relationship between the text in the natural language and the verbal text of culture. (Theses 1998: 43)

As three subtypes of this relationship there are mentioned cases where (1) a text in a natural language is not a text of a given culture (e.g., oral texts in a writing-oriented culture); (2) a text in a secondary 
language, i.e. a text of culture is at the same time also a text of language, i.e. a text in a natural language (e.g., a poem that is expressed simultaneously in a secondary, poetic language and in a primary language, for instance, in the poet's mother tongue); (3) a verbal text of culture is not a text in a natural language (e.g., a Latin prayer for Slavs).

From the modern perspective, "Theses on the Semiotic Study of Cultures" written in 1973 touched upon an important aspect virtuality: "The place of the text in the textual space is defined as the sum total of potential texts" (Theses 1998: 45). Where J. Derrida would call this sum total "discourse", J. Lotman has used the term "homeostasis". In his book Universe of the Mind (1990), expanding upon the ideas of F. de Saussure, he has claimed that "synchrony is homeostatic while diachrony is made up of a series of external and accidental infringements of it, in reacting against which synchrony reestablishes its integrity" (Lotman 1990: 6).

On the background of cultural homeostasis, the advance toward semiosphere appears as natural. Let us recall once again the alreadyquoted thought of V. Ivanov: "The task of semiotics is to describe the semiosphere without which the noosphere is inconceivable" (Ivanov 1998: 792). As noosphere is the future living environment of the humankind, created in mutual agreement and on rational principles, it follows from this definition that semiotics must assist mankind in understanding both history and future. Hence, in addition to the relationship with the present, semiosphere has also its dimensions of history and future. What is more important, however, is that semiosphere establishes the dynamics between the part and the whole:

Since all the levels of the semiosphere - ranging from a human individual or an individual text to global semiotic unities - are all like semiospheres inserted into each other, then each and one of them is both a participant in the dialogue (a part of the semiosphere) as well as the space of the dialogue (an entire semiosphere). (Lotman 1999: 33)

This whole-part relationship is joined, in turn, by the dynamics between the subjective and the objective: "The structural parallelism between semiotic characteristics of a text and of a personality enables us to define any text on any level as a semiotic personality, and to regard any personality on any sociocultural level as a text" (Lotman 1999: 66). 
The semiospherical perspective in the analysis of culture implies the establishment of textuality as an operational principle in which texts in the ordinary sense and phenomena described as texts in the interests of better comprehension exist together on equal terms. The question of their differentiation and comparability is a question of delimitation - in other words, a question of the boundaries of textuality. From the aspect of scientific accuracy, the only requirement that will stand is the traditional demand of cultural semiotics - that the position of the observer or the analyser must remain visible. This provides for the necessary degree of precision in the case where the units of analysis cannot be formalized and are not unequivocally clearcut. Textualization should not be regarded as arbitrary delimitation but as identification of different levels in the holistic dimension in culture. The universality of and necessity for this method stems from the need to preserve the interrelations between different parts of a whole and the need to see that the whole itself exists also both as a part and as a division into parts. Each particular act of communication can be analysed as such, but it can also always be shown that the relations between a prototext and its metatext are not exhausted with the creation of the typology of metatexts. Usually, the prototext itself is also in some respect already a metatext - it is difficult to envision the existence of pure original texts in culture.

Textuality of culture is accompanied by the possibility to conduct analysis on many levels. A text can be investigated as autonomous and focused at by exploring its inner workings. At the same time, it can be investigated as participating in metacommunication and here, now regarded as a prototext, the text is seen as accompanied by a number of metatexts of different kinds (see also Torop 1999: 27-41). The bulk of textual transformations ranging from translations to annotations can, on the one hand, be described from the aspect of relations between the prototext and the metatext, but on the other hand each metatext belongs to its own discourse and can be analysed as a part of this. By investigating metatexts as a textual whole it is possible to analyse the ways in which a particular prototext exists in culture. This kind of investigation makes it also possible to reconstruct a missing prototext. History of theatre provides a good example of the need for metatexts in order to describe a missing prototext. It is possible to reconstruct old untaped theatre performances, but also hypothetical primal forms of different types of fairy tales (as invariants of the later variants) etc. In addition, the investigation of the relations between a 
prototext and metatexts makes it possible to talk about the capacity of a particular text to communicate with culture, with its audience, about the possible world of the ways the text can be interpreted and understood.

Related to this, but functioning in a completely different manner, is another unity - the intertextual association of texts, where each particular text gains its meaning through relations with other texts, that is, as a part of a whole. Such association can also be interdiscursive or intermedial. Unlike metatextuality, intertextual association is more difficult to delimit and its holistic dimension many not be as concrete.

Both the metatextual and the intertextual associations are subtypes of textuality and indicate that science needs to find possibilities first to define and then to give as multifaceted explanation as possible of the functioning of a complex cultural mechanism. A science investigating culture must constantly recreate its research object, must define and re-define its borders since in culture as a living organism there constantly emerge new relations and new systems. Culture changes, culture's textuality is constant. Textuality is a possibility that culture offers to its analyser, and at the same time it is an ontological property of culture and an epistemological principle for investigating culture.

\section{References}

Assmann, Aleida 1995. Was sind kulturelle Texte? In: Poltermann, Andreas (ed.), Literaturkanon - Medienereignis - Kultureller Text. Formen interkultureller Kommunikation und Übersetzung. Berlin: Erich Schmidt Verlag, 232-244.

Geertz, Clifford 1993. The Interpretation of Cultures. London: Fontana Press.

Hjelmslev, Louis 1963. Prolegomena to a Theory of Language. Whitfield, Francis J. (trans.). Madison: University of Wisconsin Press.

Ivanov, Vyatcheslav V. 1998 = Иванов, В. Очерки по предыстории и истории семиотики. In: Иванов, В., Избранные труды по семиотике и истории культуры. Т. 1. Москва: Языки русской культуры, 605-811.

Lotman, Juri 1990. Universe of the Mind: A Semiotic Theory of Culture. London: I. B.Tauris.

- 1999. Semiosfäärist. Tallinn: Vagabund.

Pjatigorskij, Alexander M. 1996. = Пятигорский, А. Заметки из 90-х о семиотике 60-х годов. In: Пятигорский, А., Избранные труды. Москва: Языки русской культуры, 52-57. 


\section{Peeter Torop}

Theses 1998 [1973]. Theses on the Semiotic Study of Cultures. (Tartu Semiotics Library 1.) Tartu: Tartu University Press.

Torop, Peeter 1995-1996. = Тороп, П. Статус Тынянова. In: Ceдbмыле тыняновские чтения: Материаль для обсуждения. Рига, 49-58.

- 1999. Kultuurimärgid. Tartu: Ilmamaa.

Tynianov, Juri 1977 = Ю. Тынянов. Поэтика. История литературы. Кино. Москва: Наука.

Saussure, Ferdinand de 1977 = Соссюр Ф. де. Труды по языкознанию. Москва: Прогресс.

White, Hayden 1989. New historicism: A comment. In: Veeser, Harold Aram (ed.), The New Historicism. New York: Routledge, 293-302.

\section{Семиосферическое понимание: текстуальность}

Семиосферический подход к семиотике (культуры) приводит к необходимости сопоставления нескольких терминологических полей. В число самых важных входят поля текстуальности, хронотопичности и мультимодальности или -медийности. Поле текстуальности связано с развитием семиотики культуры исходя прежде всего из работ Ю. Лотмана, поле хронотопичности восходит к работам М. Бахтина и у истоков мультимодальности или -медийности лежат труды Р. Якобсона. Именно в результате переплетения этих трёх терминологических и концептуальных полей можно говорить как о методологической, так и о метаязыковой интерференции, результатом которой является креолизация и гибридизация метаязыка. Но те же процессы происходят внутри указанных полей и поэтому целесообразно рассмотреть эти поля отдельно. Данная статья посвящена первому из них, полю текстуальности.

Текстуальность обозначает в данной статье некоторый общий принцип при помощи которого можно наблюдать и осмыслять разные аспекты действия культуры. Понятие текстуальности призвано соединять два полюса, между которыми располагаются основные проблемы описания и толкования культур. Один полюс обозначается бинарностью статика-динамика, второй бинарностью часть-иелое.

В текстуальности объединяются текст как обрамлённый артефакт и текстуализация как абстракция (изображение или обрамление текстом). В культуре могут быть конкретному и абстрактному текстам заданы те же вопросы, хотя абстрактный текст является лишь операциональным приёмом текстуализации явлений в целях системного и целостного анализа. Практика текстуализации способствует пониманию необходимости различения членения на основе материала текста и членения на основе текстуальности (текстуализа- 
ции) - первое обеспечивает сравнимость текстов, созданных из одного материала, второе обеспечивает сравнимость всех текстуализированных явлений вне зависимости от их материала.

Текстуальность — это возможность, предлагаемая аналитику культурой, будучи одновременно онтологическим признаком культуры и эпистемологическим принципом её исследования.

\section{Semiosfääriline mõistmine: tekstuaalsus}

Semiootika ja eriti kultuurisemiootika semiosfääriline käsitlemine toob kaasa mitme terminivälja kõrvutamise vajaduse. Olulisemate seas tuleks nimetada tekstuaalsuse, kronotoobilisuse ja multimodaalsuse ehk multimeedialisuse välja. Tekstuaalne väli on seotud kultuurisemiootika arenguga eriti Juri Lotmani töid silmas pidades, kronotoobiline väli on saanud alguse Mihhail Bahtini töödest ja multimodaalsuse (multimeedialisuse) lätete juures on Roman Jakobsoni uurimused. Just nende kolme terminoloogilise ja kontseptuaalse välja põimumisel on tekkinud nii metodoloogiline kui metakeeleline interferents, mille tulemusena me oleme sunnitud rääkima metakeele kreoliseerumisest ja hübridiseerumisest. Kuid samad protsessid toimuvad ka nende väljade sees ja seetõttu on otstarbekas ka neid välju kõigepealt eraldi vaadelda. Käesolev artikkel on pühendatud neist esimesele, tekstuaalsuse väljale.

Tekstuaalsus tähistab käesolevas artiklis üldisemat printsiipi, mille abil on võimalik jälgida ja mõtestada kultuuri toimimise erinevaid aspekte. Tekstuaalsuse mõiste on mõeldud ühendama kaht poolust, mille vahel kultuuride kirjeldamise ja seletamise põhiprobleemid paiknevad. Üht poolust tähistab binaarsus staatika - dünaamika, teist poolust binaarsus osa-tervik.

Tekstuaalsus ühendab endas teksti kui kindlapiirilise artefakti ja tekstualiseerimise kui abstraktsiooni (tekstina kujutamise või piiritlemise). Kultuuris võime konkreetsele tekstile ja abstraktsele tekstile esitada põhimõtteliselt samu küsimusi, kuigi abstraktne tekst on vaid operatsionaalne võte piiritleda tekstualiseerimise abil mõnd nähtust holistliku ja süsteemse analüüsi huvides. Tekstualiseerimise praktika omakorda aitab mõista vajadust eristada tekstimaterjalist tulenevat liigendust ja tekstuaalsusest või tekstualiseerimisest tulenevat liigendust - esimene tagab võrreldavuse samast materjalist loodud tekstide vahel, teine teeb võrreldavaks kõik tekstualiseeritud nähtused nende materjalist sõltumata.

Tekstuaalsus on võimalus, mida kultuur analüütikule pakub, olles samaaegselt kultuuri ontoloogiline tunnus ja kultuuri uurimise epistemoloogiline printsiip. 